\title{
Persepsi Mahasiswa Terhadap Program Diet Plastik di DKI Jakarta Sebagai Upaya Penyelamatan Ekosistem Laut
}

\author{
Aulia Fi Jalatami ${ }^{*}$, Tiara Putri Chaerunnisa ${ }^{1}$, Ade Suryanda ${ }^{1}$ \\ ${ }_{1}^{1}$ Universitas Negeri Jakarta, Jl. Rawamangun Muka, RT.11/RW.14, Rawamangun, Pulo Gadung, \\ Kota Jakarta Timur, Daerah Khusus Ibukota Jakarta 13220
}

Kata Kunci:

ekosistem laut, program diet plastik

\begin{abstract}
Abstrak
Laut dianggap sebagai tempat pembuangan limbah karena volume air yang besar dan kemampuan mengencerkan segala jenis zat asing. Pencemaran laut tidak dihiraukan oleh masyarakat selama bertahuntahun, dan berangsur-angsur menimbulkan dampak pencemaran dari pembuangan limbah tersebut. Limbah yang dibuang ke laut semakin banyak dan berkonsentrasi tinggi. Jika pembuangan limbah ke laut dilakukan secara berkelanjutan, dikhawatirkan akan menimbulkan dampak global dari pencemaran laut. Tujuan penelitian ini untuk mengetahui persepsi mahasiswa terhadap program diet plastik sebagai upaya penyelamatan ekosistem laut. Penelitian ini menggunakan metode deskriptif kualitatif, dengan penyebaran kuesioner, dengan responden mahasiswa di DKI Jakarta. Dari hasil penelitian yang didapatkan dari 31 sampel diketahui bahwa persepsi mahasiswa yang menempuh pendidikan di DKI Jakarta terhadap program diet plastik sebagai upaya penyelamatan ekosistem laut sangat positif dan mendukung adanya gerakan tersebut. Hal tersebut dibuktikan dengan pengetahuan mahasiswa tentang pentingnya menjaga ekosistem laut, bahaya limbah plastik terhadap ekosistem laut, dan upaya menyukseskan program diet plastik di DKI Jakarta.
\end{abstract}

Keywords:

marine ecosystem, plastic diet program

\begin{abstract}
The sea is considered a waste disposal place because of its large volume of water and the ability to dilute all kinds of foreign substances. The community has ignored marine pollution for many years and gradually causes pollution effects from waste disposal. More and more waste is being dumped into the sea and has a high concentration. If waste disposal into the sea is carried out sustainably, it is feared that it will cause global impacts from marine pollution. The purpose of this study was to determine student perceptions of the plastic diet program as an effort to save marine ecosystems. This study uses a qualitative descriptive method, with the
\end{abstract}

\footnotetext{
*Penulis koresponden: auliafijalatami_1304620054@mhs.unj.ac.id
} 
distribution of questionnaires, with respondents being a student in DKI Jakarta. From the research results obtained from 31 samples, the perception of students studying in DKI Jakarta towards the plastic diet as an effort to save the marine ecosystem is very positive and supports the movement. This finding is evidenced by the student's knowledge of the importance of maintaining marine ecosystems, the dangers of plastic waste, and efforts to make the plastic diet program successful in DKI Jakarta.

\section{PENDAHULUAN}

Secara astronomis wilayah Indonesia terletak pada $6^{\circ}$ lintang utara sampai $11^{\circ}$ lintang selatan dan $92^{\circ}$ bujur timur sampai $142^{\circ}$ bujur timur. Indonesia terdiri atas pulau-pulau yang jumlahnya kurang lebih 17.504 pulau dengan tiga perempat wilayahnya berupa laut. Berdasarkan UNCLOS 1982, total luas wilayah laut Indonesia adalah 5,9 juta $\mathrm{km}^{2}$ (Lasabuda, 2013).

Ekosistem merupakan susunan makhluk hidup serta tak hidup atau lingkungannya. Komponen penyusun ekosistem dibedakan menjadi komponen biotik dan komponen abiotik. Hubungan antara makhluk hidup dengan lingkungannya merupakan hubungan timbal balik yang kompleks. Keseimbangan ekosistem dapat terjadi apabila terdapat hubungan timbal balik antara komponenkomponen penyusun ekosistem (Sitanggang, 2015).

Ekosistem laut dikatakan juga sebagai ekosistem bahari, yaitu ekosistem yang berada di perairan laut, yang tersusun atas ekosistem perairan dalam, ekosistem pantai pesisir dangkal/bitarol serta ekosistem pasang surut. Ekosistem air laut memiliki ciri-ciri yaitu: (1) Salinitas tinggi terutama pada daerah tropis, sedangkan pada daerah dingin salinitas cukup rendah; (2) Ekosistem laut tidak dipengaruhi oleh iklim serta cuaca; (3) Arus laut selalu berputar timbul dikarenakan perbedaan temperatur serta perputaran bumi (Arianto, 2017).

Berdasarkan Undang-undang No. 32 tahun 2009 tentang Perlindungan dan Pengelolan Lingkungan Hidup Pasal 1 ayat (14) yang menyebutkan bahwa "Pencemaran lingkungan hidup adalah masuk atau dimasukkannya makhluk hidup, zat, energi, dan/atau komponen lain ke dalam lingkungan hidup oleh kegiatan manusia sehingga melampaui baku mutu lingkungan hidup yang telah ditetapkan". Pencemaran laut dapat disebabkan oleh plastik yang tidak terurai dengan jumlah limbah yang semakin lama semakin membesar dan menimbulkan dampak yang merugikan (Asia, 2017).

Sampah plastik yang dibuang akan terapung dan kemudian terendap di lautan. Sampah plastik yang terdapat di lautan massanya diperkirakan menumpuk hingga seratus juta metrik ton. Kondisi tersebut sangat buruk serta sangat sulit terurai oleh bakteri (Cordova, 2017).

Asosiasi Industri Plastik Indonesia (INAPLAS) dan Badan Pusat Statistik (BPS) memperoleh data bahwa Indonesia menjadi penyumbang sampah plastik terbesar kedua di dunia. Sampah plastik di Indonesia mencapai 64 juta ton/ tahun dimana 3,2 juta ton di antaranya merupakan sampah plastik yang dibuang ke laut (Puspita, 2018).

Penggunaan sampah plastik di masyarakat sangat tinggi, hal tersebut dikarenakan plastik bersifat fungsional. Plastik merupakan alat yang digunakan sekali pakai, sehingga plastik memiliki kehigienisan yang tinggi serta produksinya memerlukan biaya yang rendah sehingga plastik dapat diproduksi secara masal dan mudah ditemukan. Penggunaan plastik yang tinggi mengakibatkan masyarakat memiliki ketergantungan pada plastik. Ketergantungan tersebut dapat menimbulkan kerusakan ekosistem pada laut (Wahyudin, 2020).

Sampah plastik memiliki dampak ekologi dan ekonomi yang luas pada lingkungan laut. Dampak negatif langsung yang timbul akibat perkembangan jumlah sampah plastik yang sangat banyak pada organisme laut salah satunya yaitu terjeratnya organisme oleh sampah plastik serta penyumbatan saluran pencernaan (Cordova, 2017).

Menurut pendapat Menteri Kelautan dan Perikanan Republik Indonesia, Susi Pudjiastuti, sampah plastik yang terbuang ke laut akan terurai menjadi partikel-partikel kecil dengan 
ukuran 0,3-5 millimeter, partikel tersebut biasa dikenal dengan microplastics. Microplastic tersebut sering dikonsumsi oleh hewan laut (Puspita, 2018).

Sekitar tahun 2018 satu ekor ikan paus jenis Physeter Macrocephalus di wilayah laut Pulau Kapota, Kabupaten Wakatobi, Sulawesi Tenggara ditemukan mati oleh nelayan setempat. Dalam perut ikan paus tersebut ditemukan 5,9 $\mathrm{kg}$ sampah plastik (World Wide Fund for Nature, 2018).

Masyarakat saat ini sudah memiliki banyak cara untuk mengurangi dampak negatif dari sampah plastik dengan menerapkan konsep 3R yaitu singkatan dari Reuse, Reduce, dan Recycle. Salah satu konsep daur ulang jenis Recycle adalah Pirolisis yaitu mengolah atau memproses sampah plastik menjadi bahan bakar. Selain untuk mengurangi jumlah sampah plastik, proses pirolisis sangat bermanfaat karena dapat menghasilkan bahan bakar minyak dengan nilai energi yang cukup tinggi. Dari kegiatan recycle dengan proses Pirolisis $1 \mathrm{~kg}$ sampah plastik jenis Polyolefin, misalnya, dapat menghasilkan $950 \mathrm{ml}$ bahan bakar minyak (Wahyudi, 2018:58).

Peraturan Gubernur (Pergub) Nomor 142 Tahun 2019 tentang Kewajiban Penggunaan Kantong Belanja Ramah Lingkungan mulai berlaku dengan sanksi dikenakan berupa teguran tertulis, uang paksa atau denda sebesar Rp. 5 juta hingga Rp. 25 juta, pembekuan izin, hingga pencabutan izin.

\section{METODE PENELITIAN}

Penelitian ini menggunakan metode deskriptif kualitatif. Berdasarkan Bodan dan Taylor (dalam Moleong, 2012: 3), pendekatan secara kualitatif sebagai prosedur penelitian yang menghasilkan data deskriptif berupa kata kata tertulis maupun lisan dari orang atau sumber yang diamati.

Jenis penelitian yang penulis gunakan adalah penelitian kualitatif deskriptif. Pengumpulan data yang digunakan adalah kuesioner. Kuesioner sendiri merupakan susunan daftar pertanyaan untuk mendapatkan tanggapan dari respon terkait topik yang diinginkan oleh peneliti (Riduwan, 2015).

Penyebaran kuesioner ini bertujuan untuk mengetahui persepsi Mahasiswa terhadap program diet plastik di DKI Jakarta sebagai upaya penyelamatan ekosistem laut. Penyebaran kuesioner menggunakan metode probability sampling, yaitu peneliti menggunakan sampel secara acak dimana anggota populasi akan memiliki peluang yang sama untuk menjadi anggota sampel. Populasi terdiri dari mahasiswa yang berdomisili di DKI Jakarta.

Populasi dalam penelitian ini adalah mahasiswa aktif yang menempuh pendidikan di daerah DKI Jakarta. Sampel yang diperoleh yaitu sebanyak 31 orang mahasiswa.

Peneliti telah melakukan survey melalui penyebaran kuesioner guna mengetahui persepsi mahasiswa yang menempuh pendidikan di daerah DKI Jakarta terhadap program diet plastik yang digalakan pemda DKI Jakarta sebagai upaya penyelamatan ekosistem laut.

\section{HASIL DAN PEMBAHASAN}

Berdasarkan hasil survey yang dilakukan terhadap mahasiswa yang menempuh pendidikan di DKI Jakarta, maka diperoleh hasil sebagai berikut.

\section{Persepsi Mahasiswa Mengenai Ekosistem Laut.}

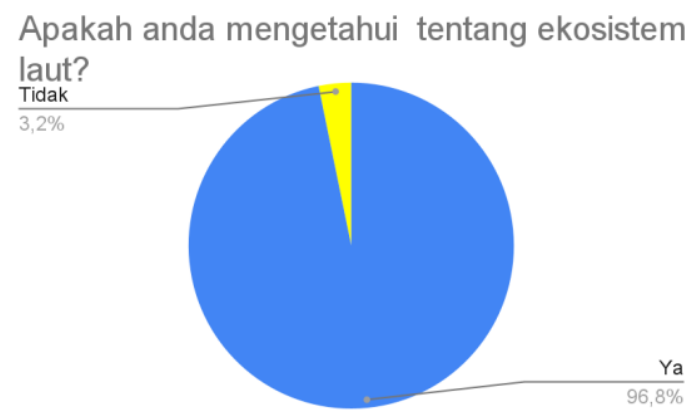

Diagram 1. Pengetahuan mahasiswa terhadap ekosistem laut.

Berdasarkan diagram 1 untuk pertanyaan mengenai ekosistem laut, mayoritas mahasiswa menjawab "ya" (sebanyak 96.8\%) yang menunjukan bahwa mayoritas mahasiswa yang menempuh pendidikan di DKI Jakarta mengetahui ekosistem laut. 


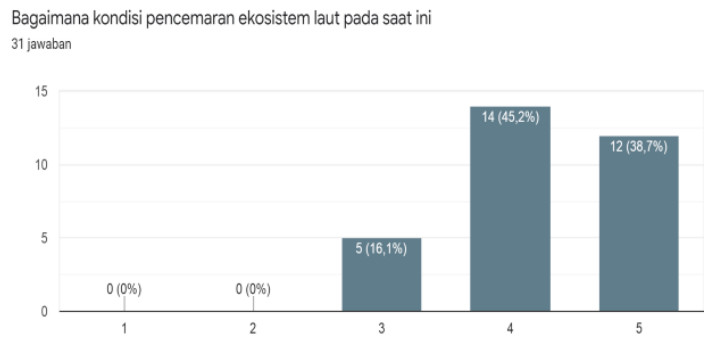

Diagram 2. Pandangan mahasiswa terhadap kondisi pencemaran ekosistem laut pada saat ini.

Berdasarkan diagram 2 untuk pertanyaan mengenai kondisi pencemaran ekosistem laut pada saat ini, $38,7 \%$ mahasiswa yang menempuh pendidikan di daerah DKI Jakarta berpersepsi bahwa pencemaran ekosistem laut pada saat ini sangat buruk, 45,2\% mahasiswa berpersepsi kondisi pencemaran ekosistem laut buruk, dan 16,1\% mahasiswa berpersepsi pencemaran laut tidak begitu buruk atau bisa dikatakan pencemaran laut rendah.

Apakah anda mengetahui bahwa sampah plastik dapat mencemari ekosistem laut?

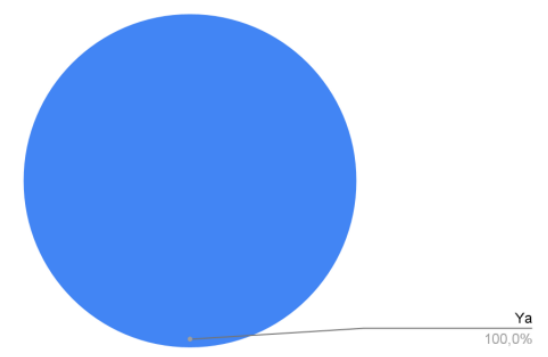

Diagram 3. Pengetahuan mahasiswa bahwa sampah plastik dapat mencemari ekosistem laut.

Berdasarkan diagram 3, sebanyak 100\% responden menjawab "ya" yang menunjukan bahwa sebanyak 31 mahasiswa yang menempuh pendidikan di DKI Jakarta mengetahui bahwa sampah plastik dapat mencemari ekosistem laut.

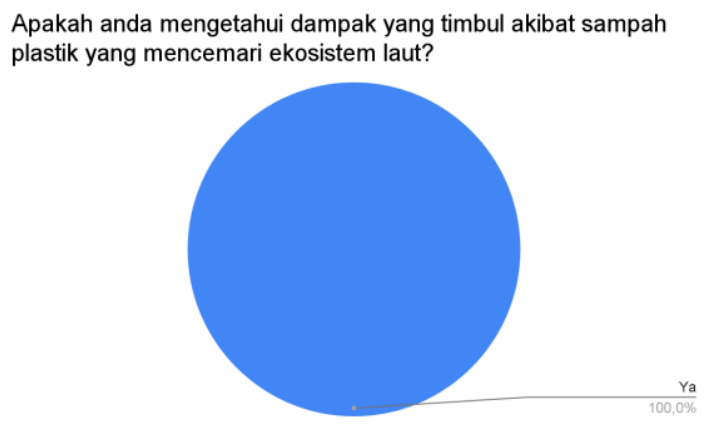

Diagram 4. Pengetahuan mahasiswa terhadap dampak yang timbul akibat sampah plastik yang mencemari ekosistem laut.
Pada diagram 4 dengan pertanyaan "apakah mahasiswa mengetahui dampak yang timbul akibat sampah plastik yang mencemari ekosistem laut?" sebanyak $100 \%$ responden menjawab "ya" yang menunjukan bahwa mahasiswa tersebut mengetahui dampak yang timbul akibat sampah plastik yang mencemari ekosistem laut.

Berdasarkan diagram 1, 2, 3 dan 4 maka dapat diketahui bahwa persepsi mahasiswa terhadap ekosistem laut serta dampak yang ditimbulkan akibat sampah plastik yang mencemari ekosistem laut menunjukan persepsi yang baik. Sampah plastik memiliki dampak ekologi dan ekonomi yang luas pada lingkungan laut. Dampak negatif langsung yang timbul yaitu terjeratnya organisme oleh sampah plastik (Cordova, 2017).

\section{Persepsi Mahasiswa Mengenai Program Diet Plastik}

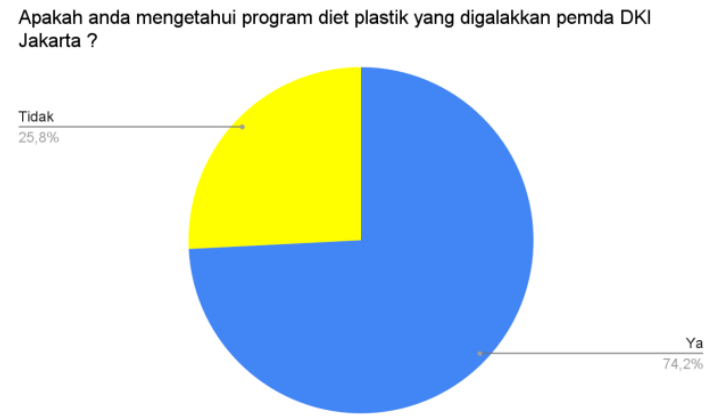

Diagram 5. Menunjukan pengetahuan mahasiswa terhadap program diet plastik. Berdasarkan diagram 5 yang menunjukan pengetahuan mahasiswa terhadap program diet plastik yang digalakkan pemda DKI Jakarta, sebanyak $74,2 \%$ responden menjawab "ya" yang menunjukan bahwa mereka mengetahui program tersebut, dan sebanyak 25,8\% responden menjawab "tidak" yang menunjukan bahwa mahasiswa tersebut tidak mengetahui program diet plastik yang digalakkan oleh pemda DKI Jakarta. 
Apakah program diet plastik dapat menyelamatkan ekosistem laut?

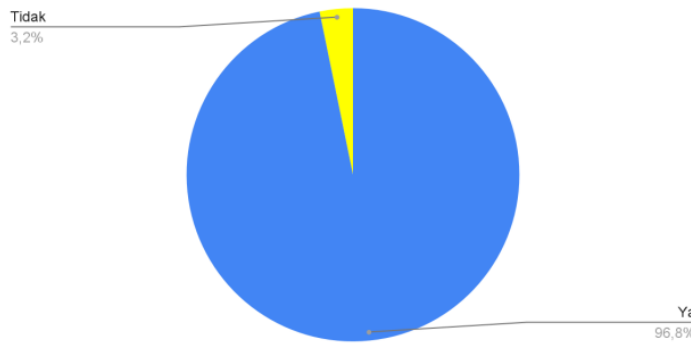

Diagram 6. Pendapat mahasiswa mengenai program diet plastik untuk menyelamatkan ekosistem laut.

Diagram 6 menunjukan bahwa sebanyak $96,8 \%$ responden menjawab "ya" yang menunjukan bahwa 30 dari 31 mahasiswa setuju bahwa program diet plastik dapat menyelamatkan ekosistem laut.

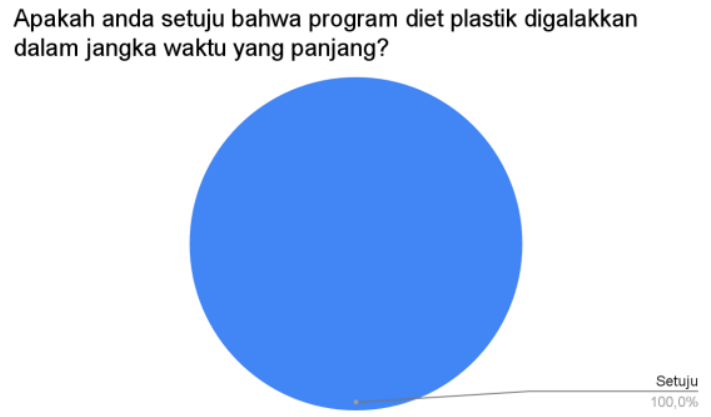

Diagram 7. Persetujuan mahasiswa terhadap pemanjangan waktu diet plastik.

Berdasarkan diagram 7 yang menyatakan persetujuan mahasiswa, sebanyak $100 \%$ responden menjawab "ya", yang menunjukan bahwa 31 mahasiswa setuju apabila program diet plastik dilaksanakan dalam jangka waktu yang lebih panjang.

Selain itu mayoritas mahasiswa berpendapat partisipasi masyarakat dalam berkontribusi terhadap program diet plastik di DKI Jakarta dengan mengurangi penggunaan plastik di kehidupan sehari-hari dan membiasakan belanja menggunakan tas belanja yang ramah lingkungan (dapat digunakan berkali-kali).

\section{PENUTUP}

Kesimpulan dari penelitian ini adalah persepsi mahasiswa terhadap program diet plastik di DKI Jakarta sengat baik, mayoritas mahasiswa berpengetahuan tentang ekosistem laut, pentingnya menjaga ekosistem laut, bahaya limbah plastik terhadap ekosistem laut, dan upaya menyukseskan program diet plastik di DKI Jakarta. Selain itu seluruh responden juga setuju program diet plastik diberlakukan dalam jangka waktu yang panjang.

\section{UCAPAN TERIMA KASIH}

Ucapan terima kasih penulis sampaikan kepada Bapak Ade Suryanda, M.Si atas dorongan serta bimbingannya serta semua pihak yang turut membantu penulis dalam penelitian ini.

\section{DAFTAR PUSTAKA}

Arianto, Henry. 2017. Urgensi Perlindungan Ekosistem Laut Terhadap Bahaya Ilegal Fishing. Lex Jurnalica Volume 14(3): 185.

Arisandi, A. 2018. Profil Terumbu Karang Pulau Kangean, Kabupaten Sumenep, Indonesia. JURNAL ILMIAH PERIKANAN DAN KELAUTAN, Vol.10 (2), 76-83.

Asia \& Muh, Zainul Arifin. 2017. Dampak Sampah Plastik Bagi Ekosistem Laut. Buletin Matric Volume 14 (1): 44.

Cordova, M Reza. 2017. Pencemaran Plastik di Laut. Oseana Volume XLII (3): 23-25.

Krisyantia. (2020). Pengaruh Kampanye \#PantangPlastik terhadap Sikap Ramah Lingkungan (Survei pada Pengikut Instagram @GreenpeaceID).JJurnal Komunikasi, Media dan Informatika, Volume. 9 (1), 40-51.

Lasabuda, Ridwan. 2013. Pembangunan Wilayah Pesisir dan Lautan dalam Perspektif Negara Kepulauan Republik Indonesia. Jurnal Ilmiah Platax Volume 1 (2): 93

Moleong, Lexy J. (2012). Metodologi Penelitian Kualitatif. Bandung. PT Remaja Rosdakarya.

Puspita, Sherly. (2018, Augustus 19). Indonesia penyumbang sampah plastik terbesar 
kedua di dunia. Tersedia pada website https://megapolitan.kompas.com/ $\mathrm{read} / 2018 / 08 / 19 / 21151811 /$ indonesiapen yumbang-sampah-plastik-terbesarkeduadi-dunia.

Sitanggang, Netty Demak H \& Yulistiana. 2015. Peningkatan Hasil Belajar Ekosistem Melalui Penggunaan Laboratorium Alam. Jurnal Formatif Volume 5(2): 158-159.

Riduwan. (2015). Skala Pengukuran Variabel Variabel Penelitian. Bandung: Alfabeta.

Wahyudi, Jatmiko. Hermain Teguh Prayitno. Arieyanti Dwi Astuti. (2018). Pemanfaatan Limbah Plastik sebagai Bahan Baku Pembuatan Bahan Bakar Alternatif. Jurnal Litbang XIV (1): 58- 67.

Wahyudin, GD. 2020. Penanggulangan Pencemaran Sampah Plastik di Laut Berdasarkan Hukum Internasional. Jurnal IUS Kajian Hukum dan Keadilan Volume 8(3): 530 . 